\title{
mRNA EXPRESSION AND ACTIVITY OF ION-TRANSPORTING PROTEINS IN GILLS OF THE BLUE CRAB CALLINECTES SAPIDUS: EFFECTS OF WATERBORNE COPPER
}

\author{
Camila M. G. Martins, Daniela Volcan Almeida, Luis Fernando Fernandes Marins, and Adalto Bianchin** \\ Instituto de Ciências Biológicas, Universidade Federal do Rio Grande (FURG), 96201-900 Rio Grande, Rio Grande do Sul, Brazil
}

(Submitted 9 March 2010; Returned for Revision 6 May 2010; Accepted 27 August 2010)

\begin{abstract}
Waterborne $\mathrm{Cu}$ effects on the transcription of genes encoding ion-transporting proteins and the activities of these proteins were evaluated in gills of the blue crab Callinectes sapidus acclimated to diluted (2\%) and full (30\%) seawater. Crabs were exposed $(96 \mathrm{~h})$ to an environmentally relevant concentration of dissolved $\mathrm{Cu}(0.78 \mu \mathrm{M})$ and had their posterior (osmoregulating) gills dissected for enzymatic and molecular analysis. Endpoints analyzed were the activity of key enzymes involved in crab osmoregulation (sodiumpotassium adenosine triphosphatase $\left[\mathrm{Na}^{+} / \mathrm{K}^{+}\right.$-ATPase], hydrogen adenosine triphosphatase $\left[\mathrm{H}^{+}\right.$-ATPase], and carbonic anhydrase $[\mathrm{CA}])$ and the mRNA expression of genes encoding these enzymes and the sodium-potassium-chloride $\left(\mathrm{Na}^{+} / \mathrm{K}^{+} / 2 \mathrm{Cl}^{-}\right)$cotransporter. Copper effects were observed only in crabs acclimated to diluted seawater (hyperosmoregulating crabs) and were associated with an inhibition of the expression of mRNA of genes encoding the $\mathrm{Na}^{+} / \mathrm{K}^{+}$-ATPase and the $\mathrm{Na}^{+} / \mathrm{K}^{+} / 2 \mathrm{Cl}^{-}$cotransporter. However, Cu did not affect $\mathrm{Na}^{+} / \mathrm{K}^{+}$-ATPase activity, indicating that the gene transcription is downregulated before a significant inhibition of the enzyme activity can be observed. This also suggests the existence of a compensatory response of this enzyme to prevent osmoregulatory disturbances after short-term exposure to environmentally relevant $\mathrm{Cu}$ concentrations. These findings suggest that $\mathrm{Cu}$ is a potential ionoregulatory toxicant in blue crabs $C$. sapidus acclimated to low salinity. The lack of $\mathrm{Cu}$ effect on blue crabs acclimated to full seawater would be due to the reduced ion uptake needed for the regulation of the hemolymph osmotic concentration in full seawater $(30 \%)$. Also, this could be explained considering the lower bioavailability of toxic $\mathrm{Cu}$ (free ion) associated with the higher ionic content and dissolved organic matter concentration in high salinity (30\%) than in diluted seawater (2\%o). Environ. Toxicol. Chem. 2011;30:206211. (C) 2010 SETAC
\end{abstract}

Keywords-Crab Copper mRNA expression Ion transporters Salinity

\section{INTRODUCTION}

Marine environmental contamination by $\mathrm{Cu}$ is most likely to occur in coastal and estuarine ecosystems as a result of human activities around these areas. In fact, $\mathrm{Cu}$ is one of the most relevant inorganic contaminants reaching coastal waters in sandy beaches in Southern Brazil. Studies on trace metal concentrations in the waters from the Patos Lagoon estuary (Rio Grande, Rio Grande do Sul, Southern Brazil) have shown significant increases (from $2 \mu \mathrm{g} / \mathrm{L}$ in early 1980 s to $34 \mu \mathrm{g} / \mathrm{L}$ in 1998) in environmental $\mathrm{Cu}$ concentration as a consequence of industrial and harbor activities [1,2].

Although $\mathrm{Cu}$ plays an essential role in a number of biological processes in crustaceans [3-5], this metal has the potential to exert toxic effects. Therefore, a homeostatic regulation for $\mathrm{Cu}$ based on mechanisms involved in metal absorption and excretion ensures sufficient amounts of $\mathrm{Cu}$ for essential processes while preventing the toxicity of $\mathrm{Cu}$ excess [6].

Aquatic organisms can take up $\mathrm{Cu}$ directly from ambient water, and elevated $\mathrm{Cu}$ concentrations lead to metal accumulation in several tissues [7-12]. Although oxidative stress is accepted as one important cause of $\mathrm{Cu}$ toxicity, other effects have been described in organs involved in osmoregulation of aquatic organisms [11]. Physiological studies have demonstrated that the key mechanism of waterborne $\mathrm{Cu}$ toxicity is associated with an impairment of $\mathrm{Na}^{+}$and $\mathrm{Cl}^{-}$regulation in both freshwater and marine osmoregulating fish and inverte-

* To whom correspondence may be addressed (adaltobianchini@furg.br).

Published online 6 October 2010 in Wiley Online Library (wileyonlinelibrary.com). brates. Generally, the gill is the main organ involved in osmotic and ionic regulation and is consequently the main target for $\mathrm{Cu}$ toxicity in these animals $[10,11,13]$.

Toxicological studies clearly indicate that gills serve as a major route of $\mathrm{Cu}$ uptake in aquatic animals. This metal can compete with other ions such as $\mathrm{Na}^{+}[10,13]$ and $\mathrm{Ca}^{2+}[14,15]$ for binding physiologically active sites at the gill, consequently being incorporated by the animal. In fact, components of $\mathrm{Na}^{+}$ transport, including the enzymes sodium-potassium adenosine triphosphatase $\left(\mathrm{Na}^{+} / \mathrm{K}^{+}\right.$-ATPase $)$, hydrogen adenosine triphosphatase $\left(\mathrm{H}^{+}\right.$-ATPase $)$, and carbonic anhydrase (CA), as well as the membrane sodium-hydrogen exchanger $\left(\mathrm{Na}^{+} / \mathrm{H}^{+}\right)$and sodium-potassium-chloride cotransporter $\left(\mathrm{Na}^{+} / \mathrm{K}^{+} / 2 \mathrm{Cl}^{-}\right)$, are involved in $\mathrm{Cu}$ transport across the gill epithelium $[11,13,16]$. Therefore, $\mathrm{Na}^{+}$transport across the gills can be affected by the presence of waterborne $\mathrm{Cu}$, resulting in osmoregulatory disturbances. In fact, the inhibition of $\mathrm{Na}^{+}$transport across the gills of the freshwater rainbow trout, Salmo gairdneri, was paralleled by inhibition of the gill $\mathrm{Na}^{+} / \mathrm{K}^{+}$-ATPase activity [7] Also, inhibition of the activity of gill CA was observed in the estuarine crab Chasmagnathus granulata in the presence of high levels of waterborne $\mathrm{Cu}$ [17]. Despite these studies, only few reports describe the biochemical and physiological effects of $\mathrm{Cu}$ on ion-transporting proteins in euryhaline invertebrates, especially at different environmental salinities. Also, information is lacking at the molecular level.

Thus, the objective of the present study was to evaluate the effect of $\mathrm{Cu}$ on the activity of key enzymes $\left(\mathrm{Na}^{+} / \mathrm{K}^{+}\right.$ATPase, $\mathrm{H}^{+}$-ATPase, and CA) involved in gill $\mathrm{Na}^{+}$transport in the blue crab Callinectes sapidus as well as on the transcription of genes encoding these enzymes and the $\mathrm{Na}^{+} / \mathrm{K}^{+} / 2 \mathrm{Cl}^{-}$ 
cotransporter. Given that $C$. sapidus is an euryhaline species living in estuaries and coastal areas, $\mathrm{Cu}$ effects were evaluated at two ambient salinities ( 2 and $30 \%$ ), corresponding to two different physiological conditions (hyperosmoregulating and osmoconforming blue crabs, respectively) $[18,19]$.

\section{MATERIALS AND METHODS}

\section{Experimental animals and $\mathrm{Cu}$ exposure}

Experiments were performed on adult male blue crabs (Callinectes sapidus) in stage $\mathrm{C}$ or early D of the intermolt cycle [20] collected from nonmetal-contaminated sites at the Patos Lagon estuary (Rio Grande, Rio Grande do Sul, Southern Brazil) [2,21]. Crabs were collected, transferred to the laboratory, and acclimated to diluted $(2 \%)$ or full $(30 \%)$ seawater for at least two weeks, as previously described [22]. Low salinity $(2 \%)$ was obtained by diluting full seawater with distilled water. Acclimation media were continuously filtered (chemical and biological filters) and aerated. Temperature and photoperiod were fixed at $20^{\circ} \mathrm{C}$ and $12: 12$-h light:dark, respectively. Three times a week, crabs were fed until satiation with chopped fish.

Acclimated crabs were acutely exposed (96h) to $\mathrm{Cu}$ (nominal $=1 \mu \mathrm{M} \mathrm{Cu}$ as $\mathrm{CuCl}_{2}$ ) using filtered seawater (5- $\mu \mathrm{m}$-mesh filter) at salinity 2 or $30 \%$. Copper was added to the experimental media from a stock solution $(5 \mathrm{mM})$. Copper concentration was checked by atomic absorption spectrophotometry (AAS; Avanta 932 Plus; GBC) using standard solutions prepared in saltwater at the experimental salinity [12,13,23]. Copper was added to the water $3 \mathrm{~h}$ prior to crab introduction in the test chamber to allow $\mathrm{Cu}$ equilibration with the experimental medium [23]. Control exposures (no $\mathrm{Cu}$ addition to the exposure medium) were also tested in water at salinities 2 and $30 \%$.

Experimental media were completely renewed every $24 \mathrm{~h}$. At the beginning and after $24 \mathrm{~h}$ of exposure, nonfiltered and filtered $(0.45-\mu \mathrm{m}$-mesh filter) water samples were collected from the experimental media for further analyses of total (nonfiltered samples) and dissolved (filtered samples) $\mathrm{Cu}$ concentrations by AAS (Avanta 932 Plus; GBC), as previously described $[12,13,23]$. Six blue crabs were tested under each experimental condition.

After $\mathrm{Cu}$ exposure, crabs were cryoanesthetized and killed and had their posterior gills (gills 6-8) dissected. These gills were analyzed because they are the main organs involved in ion uptake from water in blue crabs, whereas anterior gills (gills
1-4) are considered as mainly respiratory. In C. sapidus, the fifth pair of gills is a transitional one, showing respiratory and ion-transporting functions [19]. Dissected gills were dried on filter paper. The sixth pair of gills (G6) was immediately used for RNA extraction, and the seventh pair of gills (G7) was stored $\left(-80^{\circ} \mathrm{C}\right)$ for further enzymatic assays.

RNA extraction and semiquantitative polymerase chain reaction

Total RNA was extracted from G6 using Trizol reagent (Invitrogen) and used to synthesize the complementary DNA (cDNA), using the reverse transcriptase (Superscript III RT) and the corresponding primer AP (5'-GGCCACGCGTCGACTAGTAC $\left.(\mathrm{T})_{17}-3^{\prime}\right)$, following the manufacturer's instructions (Invitrogen). cDNA produced was employed as template for gene-specific polymerase chain reaction (PCR). All reactions were performed in $12.5 \mu \mathrm{l}$ of a solution containing $1.25 \mu \mathrm{l}$ of $10 \times$ PCR buffer, $0.375 \mu \mathrm{l} \mathrm{MgCl}_{2}(50 \mathrm{mM}), 0.25 \mu \mathrm{dNTP}$ $(10 \mathrm{mM}), 0.25 \mu \mathrm{l}$ primer forward $(0.01 \mathrm{mM}), 0.25 \mu \mathrm{l}$ primer reverse $(0.01 \mathrm{mM}), 0.5 \mu \mathrm{l} \mathrm{cDNA}$ (dilution $1: 10), 0.1 \mu \mathrm{l}$ Platinum Taq polymerase $(5 \mathrm{U} / \mathrm{L})$, and $9.525 \mu \mathrm{l}$ pure water. All reagents were purchased from Invitrogen. The PCR protocol consisted of $2 \mathrm{~min}$ at $94^{\circ} \mathrm{C}, 30 \mathrm{~s}$ at $94^{\circ} \mathrm{C}, 30 \mathrm{~s}$ at $60^{\circ} \mathrm{C}, 1 \mathrm{~min}$ at $72^{\circ} \mathrm{C}$, with a final extension step of $5 \mathrm{~min}$ at $72^{\circ} \mathrm{C}$. For genes with a sequence size lower than 500 base pair (bp), the last step of the PCR cycle was $30 \mathrm{~s}$ at $72^{\circ} \mathrm{C}$. The number of cycles in the PCRs for each gene was established in order to avoid the reaction's plateau phase. Analyzed genes, number of cycles, and primer sequences used are described in Table 1. Note that the number of cycles is different between salinity 2 and $30 \%$.

The $\beta$-actin gene transcription was used to normalize data on mRNA expression. It is important to note that expression of the gill $\beta$-actin mRNA was not affected either by salinity ( 2 and $30 \%$ ) or by $\mathrm{Cu}$ exposure $(1 \mu \mathrm{M}$; see Results). Products of PCR were revealed in $2 \%$ agarose gel with ethidium bromide $(500 \mathrm{ng} / \mathrm{ml})$ and photographed. Images were analyzed by densitometry employing the 1 Dscan Ex software version 3.1 (Scanalytics).

\section{$\mathrm{Na}^{+} / \mathrm{K}^{+}$-ATPase activity assay}

The seventh pair of gills (G7) was thawed on ice, homogenized in $1 \mathrm{ml}$ cold buffer $(150 \mathrm{mM}$ sucrose, $10 \mathrm{mM}$ ethylenediaminetetraacetic acid, $50 \mathrm{mM}$ imidazole, $\mathrm{pH}$ 7.3) containing $0.1 \%$ sodium deoxycholate, and centrifuged (1 min, $4{ }^{\circ} \mathrm{C}, 10,000 \times g$; Mikro22R; Hettich). Supernatant was split in two aliquots. One aliquot was immediately frozen $\left(-80^{\circ} \mathrm{C}\right)$ for further analysis of the $\mathrm{H}^{+}$-ATPase activity; the

Table 1. Gene-specific primers used for polymerase chain reaction assays with posterior gills of the blue crab Callinectes sapidus ${ }^{\mathrm{a}}$

\begin{tabular}{|c|c|c|c|c|c|}
\hline \multirow[b]{2}{*}{ Gene $(\text { No. GB })^{b}$} & $\mathrm{AS}^{\mathrm{c}}$ & \multicolumn{2}{|c|}{$\mathrm{NC}^{\mathrm{d}}$} & \multirow[b]{2}{*}{ Forward primer $\left(5^{\prime}-3^{\prime}\right)$} & \multirow[b]{2}{*}{ Reverse primer $\left(5^{\prime}-3^{\prime}\right)$} \\
\hline & (bp) & sal & & & \\
\hline$\beta$-Actin (DQ084066) & 321 & 25 & 30 & AAGATCTGGCACCACACTTTCTA & GTGACCTTACCGACTACCTGATG \\
\hline NaK-ATPase (AF327439) & 538 & 25 & 28 & GATCAGTCACTTCATCCACATCA & GTGTGGAACTTGCTATTGGAGAC \\
\hline H-ATPase (AF189780) & 254 & 27 & 30 & TCAAGCAGGACTTTGAAGAGAAC & GTGGTTTCCCAGGTTACATGTAC \\
\hline CasCag (EF375491) & 927 & 28 & 30 & TGGTGGACTTAAGGGAGAATACA & TCTACTTCATGACCTCTATGGCA \\
\hline CasCac (EF375490) & 816 & 26 & 30 & GGTACACTGGAACAAGAGCAAGT & GTCAGGAAGTACAGTGACAAGCAA \\
\hline NKCC (AF190129) & 600 & 34 & 28 & CTATTGGCCTTATGTTCACCTTG & TAGCTTAACAGGCAGTGTTGACA \\
\hline
\end{tabular}

\footnotetext{
${ }^{\mathrm{a}} \mathrm{NaK}-\mathrm{ATPase}=$ gene of the sodium-potassium adenosine triphosphatase; H-ATPase = gene of the hydrogen adenosine triphosphatase; CasCag = gene of the carbonic anhydrase associated to gill membrane; CasCac $=$ gene of the cytoplasmic carbonic anhydrase; NaKCC $=$ gene of the sodium-potassium-chloride cotransporter.

${ }^{\mathrm{b}}$ GenBank accession number.

${ }^{\mathrm{c}} \mathrm{PCR}$ amplicon size expressed in number of base pairs (bp).

${ }^{\mathrm{d}} \mathrm{NC}=$ number of cycles used for each pair of primes for experiments performed at water salinity of 2 and $30 \%$.
} 
other was immediately used for the $\mathrm{Na}^{+} / \mathrm{K}^{+}$-ATPase activity measurement. $\mathrm{Na}^{+} / \mathrm{K}^{+}$-ATPase activity was measured by coupling ouabain-sensitive ATP hydrolysis to piruvate kinase- and lactate dehydrogenase-mediated oxidation of reduced nicotinamide adenine dinucleotide (NADH), as previously described $[12,24]$. Data were normalized to protein content in the supernatant.

\section{$H^{+}$-ATPase activity assay}

$\mathrm{H}^{+}$-ATPase activity measurements were performed in the second aliquot of the G7 supernatant obtained as described above. They were carried out following the protocol used to measure the $\mathrm{Na}^{+} / \mathrm{K}^{+}$-ATPase activity, but using $N$-ethylmaleimide $(100 \mathrm{mM}$; Sigma-Aldrich) as a specific inhibitor of the $\mathrm{H}^{+}$-ATPase [25]. Data were normalized to protein content in the supernatant.

\section{Carbonic anhydrase activity assay}

The seventh pair of gills (G7) was thawed on ice, homogenized (10\% weight:volume) in cold phosphate buffer (225 mM mannitol, $75 \mathrm{mM}$ sucrose, $10 \mathrm{mM}$ Trizma base, $10 \mathrm{mM} \mathrm{NaH}_{2} \mathrm{PO}_{4}, \mathrm{pH}$ adjusted to 7.4), sonicated on ice for $30 \mathrm{~s}$ (Sonozap 4180; Sonaer Ultrasonics), and centrifuged $(10,000 \times g)$ for $20 \mathrm{~min}$ at $4{ }^{\circ} \mathrm{C}$ (Mikro22R; Hettich). An aliquot $(200 \mu \mathrm{l})$ of the supernatant was used as enzyme source to determine the total $\mathrm{CA}$ activity. The remaining supernatant was centrifuged $(100,000 \times g)$ for $90 \mathrm{~min}$ at $4^{\circ} \mathrm{C}$ to obtain the cytoplasmic CA fraction. Gill CA activity was determined in the supernatant using the $\Delta \mathrm{pH}$ method, as previously described [17]. Data were normalized to protein content in the supernatant.

\section{Data analyses}

Data were expressed as mean \pm standard error $(n=6)$. Mean values from mRNA expression and enzyme activity data were subjected to analysis of variance, followed by the Tukey test. The significance level adopted was $95 \%(\alpha=0.05)$. Analysis of variance assumptions (data normality and homogeneity of variances) were previously verified.

\section{RESULTS}

Mean $\mathrm{Cu}$ concentrations in diluted (2\%) and full (30\%) seawater were not significantly different. Therefore, only one mean was calculated (nominal $=1 \mu \mathrm{M}$; total $\mathrm{Cu}=0.99 \pm$ $0.13 \mu \mathrm{M}$; dissolved $\mathrm{Cu}=0.78 \pm 0.10 \mu \mathrm{M}$ ). No mortality was observed in either control or $\mathrm{Cu}$-exposed crabs.

In control crabs, salinity did not affect transcription of the $\beta$-actin gene $(2 \%$ o salinity $=801.1 \pm 173.0$ densitometry units; $30 \%$ salinity $=914.8 \pm 166.3$ densitometry units). Also, waterborne $\mathrm{Cu}$ exposure did not affect $\beta$-actin mRNA expression $(2 \%$ o salinity $=619.3 \pm 34.5 ; 30 \%$ o salinity $=854.4 \pm 69.5$ densitometry units). Therefore, the mRNA expression of this gene was used to normalize the data obtained for the other genes analyzed in the present study.

In control crabs, salinity did not affect the transcription of genes encoding the ion-transporting proteins analyzed, except for that encoding the $\mathrm{Na}^{+} / \mathrm{K}^{+} / 2 \mathrm{Cl}^{-}$cotransporter. Transcription of this gene was higher in diluted seawater $(2 \%$ ) than in full seawater $(30 \%$; Table 2$)$.

In crabs acclimated to diluted seawater (2\%o), waterborne $\mathrm{Cu}$ exposure markedly inhibited the expression of mRNA encoding the $\mathrm{Na}^{+} / \mathrm{K}^{+}$-ATPase enzyme (88\% inhibition) and for the $\mathrm{Na}^{+} /$ $\mathrm{K}^{+} / 2 \mathrm{Cl}^{-}$cotransporter ( $87 \%$ inhibition). Although the $\mathrm{Cu}$ effect
Table 2. Gene transcription (target mRNA/ $\beta$-actin mRNA) of the sodiumpotassium adenosine triphosphatase (NaK-ATPase gene), hydrogen adenosine triphosphatase (H-ATPase gene), membrane carbonic anhydrase

(CasCag gene), cytoplasmic carbonic anhydrase (CasCac gene), and sodium-potassium-chloride cotransporter (NaKCC gene) in posterior gills (sixth pair of gills) of the blue crab Callinectes sapidus kept under control condition (no copper addition to the water) or acutely exposed (96h) to waterborne $\mathrm{Cu}(1 \mu \mathrm{M})$ at water salinity of 2 and $30 \%{ }^{\mathrm{a}}$

\begin{tabular}{lccccc}
\hline & \multicolumn{2}{c}{ Salinity $2 \% 0$} & & \multicolumn{2}{c}{ Salinity $30 \%$} \\
\cline { 2 - 3 } \cline { 5 - 6 } Gene & Control & Copper & & Control & Copper \\
\hline NaK-ATPase & $1.32 \pm 0.72 \mathrm{~A}$ & $0.16 \pm 0.10 \mathrm{~B}$ & $1.26 \pm 0.15 \mathrm{~A}$ & $1.03 \pm 0.24 \mathrm{AB}$ \\
H-ATPase & $0.84 \pm 0.34 \mathrm{~A}$ & $0.34 \pm 0.03 \mathrm{~A}$ & & $0.50 \pm 0.13 \mathrm{~A}$ & $0.51 \pm 0.12 \mathrm{~A}$ \\
CasCAg & $1.59 \pm 0.63 \mathrm{~A}$ & $1.62 \pm 0.52 \mathrm{~A}$ & $1.57 \pm 0.26 \mathrm{~A}$ & $1.23 \pm 0.32 \mathrm{~A}$ \\
CasCac & $1.72 \pm 0.16 \mathrm{~A}$ & $2.06 \pm 0.48 \mathrm{~A}$ & $1.73 \pm 0.62 \mathrm{~A}$ & $1.72 \pm 0.14 \mathrm{~A}$ \\
NaKCC & $0.85 \pm 0.30 \mathrm{~A}$ & $0.11 \pm 0.07 \mathrm{~B}$ & $0.40 \pm 0.04 \mathrm{~B}$ & $0.31 \pm 0.08 \mathrm{~B}$ \\
\hline
\end{tabular}

${ }^{\text {a }}$ Data are expressed as mean \pm standard error $(n=3-6)$. Different uppercase letters indicate significantly different mean values $(p<0.05)$ between treatments and salinities tested for each gene.

on the transcription of gene encoding the $\mathrm{H}^{+}$-ATPase was not significant, an important reduction (60\% inhibition) was also observed. On the other hand, $\mathrm{Cu}$ exposure did not significantly affect the expression of the mRNA encoding for the ion-transporting proteins analyzed in crabs acclimated to full seawater (30\%o; Table 2). Waterborne $\mathrm{Cu}$ exposure did not significantly change the $\mathrm{Na}^{+} / \mathrm{K}^{+}$-ATPase (Fig. 1), $\mathrm{H}^{+}$-ATPase (Fig. 2), total CA (Fig. 3A), or cytoplasmic CA (Fig. 3B) activity in gill of blue crabs acclimated to diluted or full seawater.

\section{DISCUSSION}

In crustaceans inhabiting diluted seawater or freshwater, such as the blue crab Callinectes sapidus, active transbranchial $\mathrm{NaCl}$ absorption constitutes one element of the hyperosmoregulatory process. The other element is represented by water excretion. Both processes have been intensively studied in many species. The diffusive loss of ions from the hemolymph to the diluted media is compensated by actively pumping $\mathrm{Na}^{+}$ and $\mathrm{Cl}^{-}$across the gills, especially the posterior ones. These

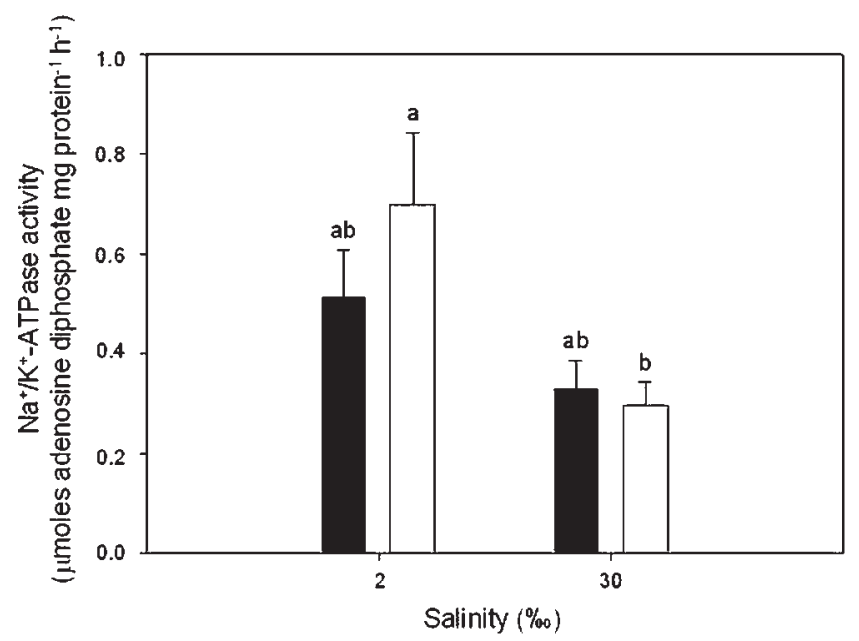

Fig. 1. Sodium-potassium adenosine triphosphatase $\left(\mathrm{Na}^{+} / \mathrm{K}^{+}\right.$-ATPase $)$ activity in the seventh pair of gills (G7) of the blue crab Callinectes sapidus kept under control conditions (solid bars) or acutely exposed ( $96 \mathrm{~h}$ ) to waterborne copper ( $1 \mu \mathrm{M}$; open bars) at water salinity of 2 and $30 \%$. Data are expressed as mean \pm standard error $(n=6)$. Different lowercase letters indicate significantly different mean values $(p<0.05)$ between treatments and salinities tested. 


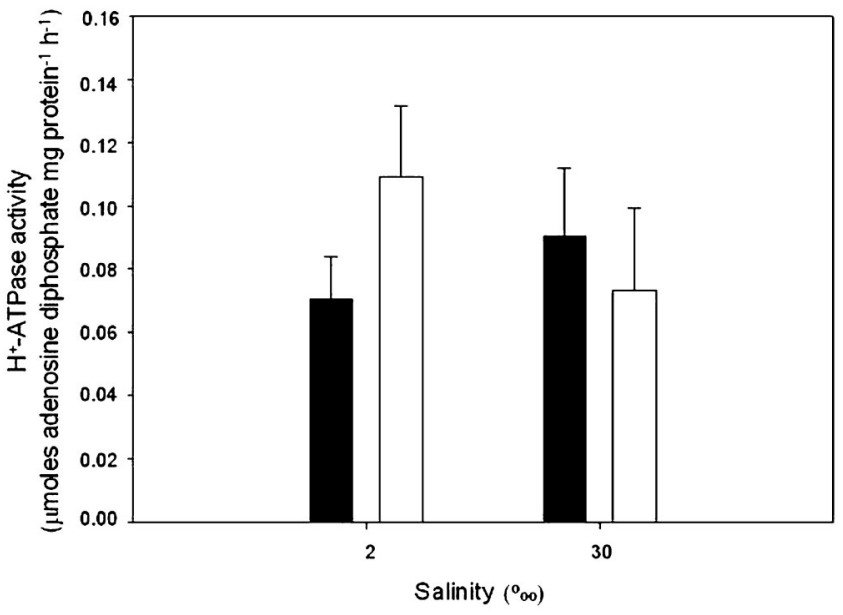

Fig. 2. Hydrogen adenosine triphosphatase $\left(\mathrm{H}^{+}\right.$-ATPase $)$activity in the seventh pair of gills (G7) of the blue crab Callinectes sapidus kept under control conditions (solid bars) or acutely exposed $(96 \mathrm{~h})$ to waterborne copper ( $1 \mu \mathrm{M}$; open bars) at water salinity of 2 and 30\%. Data are expressed as mean \pm standard error $(n=6)$. No significant difference $(p>0.05)$ was observed between treatments ( $\mathrm{Cu}$ exposure and salinities).
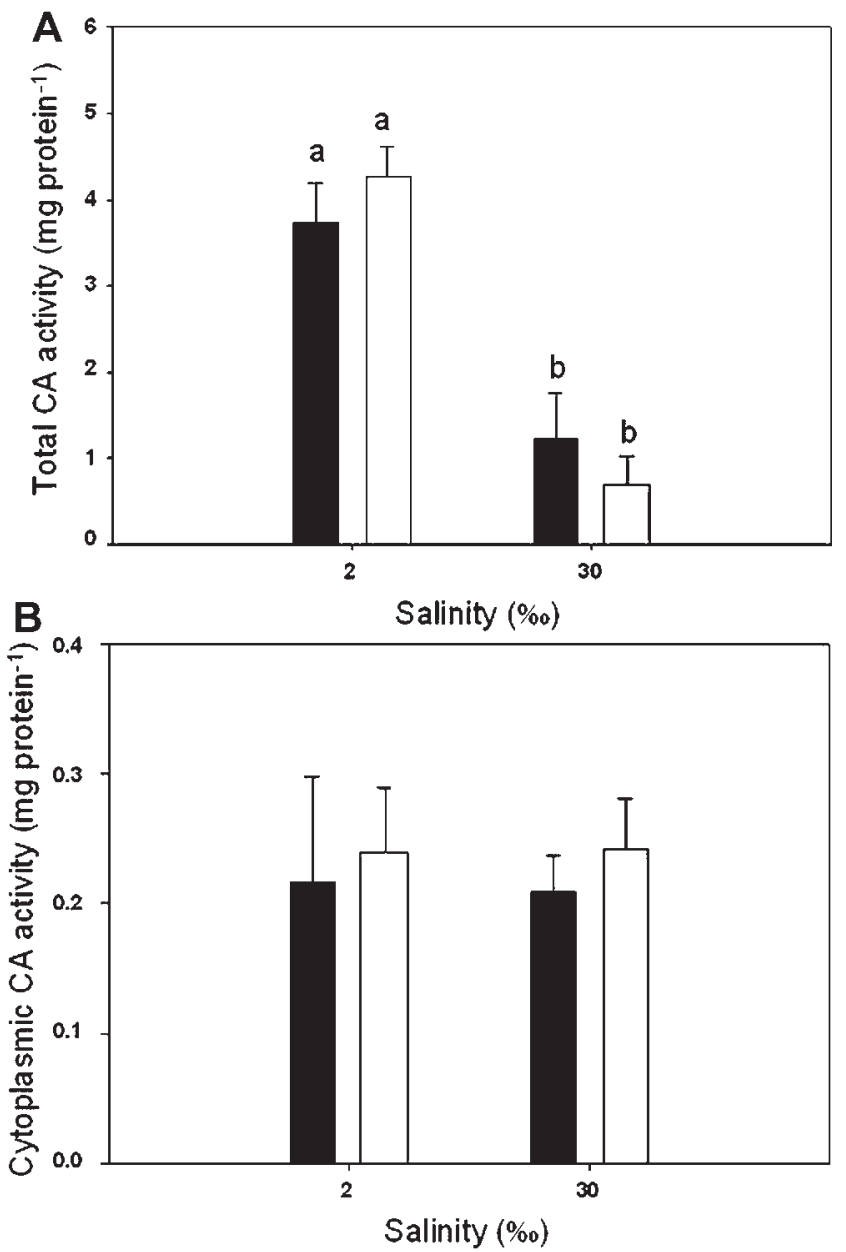

Fig. 3. Total (A) and cytoplasmic (B) carbonic anhydrase (CA) activity in the pair of gills 7 (G7) of the blue crab Callinectes sapidus kept under control conditions (solid bars) or acutely exposed $(96 \mathrm{~h})$ to waterborne copper $(1 \mu \mathrm{M}$; open bars) at water salinity of 2 and 30\%. Data are expressed as mean \pm standard error $(n=6)$. For total CA activity, different letters indicate significantly different mean values $(p<0.05)$ between treatments and salinities tested. For cytoplasmic CA, no significant difference $(p>0.05)$ was observed between treatments ( $\mathrm{Cu}$ exposure and salinities). gills show higher activities of enzymes related to ion transport, especially the $\mathrm{Na}^{+} / \mathrm{K}^{+}$-ATPase and have more mitochondriarich cells than the anterior ones. Otherwise, anterior gills are considered as largely respiratory, showing passive $\mathrm{Na}^{+}$movements. On the other hand, most crustacean species living in seawater are osmoconformers. In this case, the total osmotic pressure of their hemolymph is nearly identical to that of seawater. Therefore, the osmotic stress is minimal and activity of the mechanisms involved in the regulation of the hemolymph osmotic concentration is reduced [26-28]. For example, the blue crab $C$. sapidus hyperosmoregulates its hemolymph osmotic concentration in low-salinity water and acts as an osmoconformer species in water of salinities above $27 \%$ $[19,29]$. In the present study, the response of the blue crabs to $\mathrm{Cu}$ exposure was analyzed at these two different osmotic conditions (2 and 30\% salinities).

In the present study, $\mathrm{Cu}$ was tested at $1 \mu \mathrm{M}$ (nominal concentration) in both experimental salinities (2 and 30\%o). This concentration was selected based on the fact that at $1 \mu \mathrm{M}$ virtually all $\mathrm{Cu}$ is dissolved in saltwater, whereas significant metal precipitation is observed at higher $\mathrm{Cu}$ concentrations in the experimental salinities tested in the present study. Also, $\mathrm{Cu}$ was tested at $1 \mu \mathrm{M}$ because a significant metal accumulation in the gills (anterior and posterior gills) of the blue crab $C$. sapidus was observed at that concentration in both experimental salinities ( 2 and $30 \%$ ). However, very low crab mortality rates were observed [30]. As expected, no mortality was observed in the present study when crabs were exposed to $0.78 \mu \mathrm{M}$ dissolved $\mathrm{Cu}$ in both experimental salinities ( 2 and 30\%o). In fact, the dissolved $\mathrm{Cu}$ concentration tested in the present study $(0.78 \mu \mathrm{M})$ corresponded to 14.4 and $1.47 \%$ of the $96-\mathrm{h}$ LC50 (5.40 and $52.99 \mu \mathrm{M}$ ) for blue crabs $C$. sapidus exposed to $\mathrm{Cu}$ at 2 and 30\% salinity, respectively [30]. Therefore, the dissolved $\mathrm{Cu}$ concentration tested in the present study $(0.78 \mu \mathrm{M})$ can be considered as sublethal and environmentally relevant. This statement is based on the fact that dissolved $\mathrm{Cu}$ concentrations close to that tested in the present study have been observed in estuarine waters where the blue crab $C$. sapidus is abundant [2].

In blue crabs acclimated to seawater (30\% salinity), $\mathrm{Cu}$ did not affect gene transcription (Table 2) or activity of the iontransporting proteins analyzed (Figs. 1-3). Little or no variation in $\mathrm{Na}^{+} / \mathrm{K}^{+}$-ATPase activity was observed in seawater fish [11] and crustaceans [12] exposed to $\mathrm{Cu}$ as well. The lack of a $\mathrm{Cu}$ effect in seawater crustaceans, including the blue crab C. sapidus, would be due to the reduced ion uptake needed for regulation of the hemolymph osmotic concentration in seawater $(30 \%)$. Also, reduced $\mathrm{Cu}$ toxicity resulting from the lower free metal bioavailability in seawater [12] cannot be ruled out.

Waterborne $\mathrm{Cu}$ exposure, however, inhibited transcription of the gene encoding the gill $\mathrm{Na}^{+} / \mathrm{K}^{+}$-ATPase of blue crabs acclimated to low salinity (2\%; Table 2$)$. However, no significant effect was observed on the enzyme activity (Fig. 1). These findings indicate, for the first time, that the gene transcription is down-regulated at an environmentally relevant $\mathrm{Cu}$ concentration, before a significant inhibition of the enzyme activity can be observed. In fact, $\mathrm{Cu}$ is reported as an osmoregulatory toxicant to both freshwater fish [31] and crustaceans [32]. Furthermore, this toxicity is clearly related to an inhibition of the gill $\mathrm{Na}^{+} / \mathrm{K}^{+}$-ATPase activity. Free $\mathrm{Cu}$ has shown to bind covalent $\mathrm{SH}$ groups of $\mathrm{Na}^{+} / \mathrm{K}^{+}$-ATPase, thus interfering with conformational changes of the protein. Also, $\mathrm{Cu}$ is able to interact specifically with $\mathrm{Na}^{+} / \mathrm{K}^{+}$-ATPase magnesium binding sites, readily inhibiting the activity of this pump $[33,34]$. 
$\mathrm{Na}^{+} / \mathrm{K}^{+}$-ATPase activity in blue crabs can be modulated by insertion of pre-existing enzyme units into the cell membrane or synthesis of new enzyme units [29]. Considering that $\mathrm{Cu}$ exposure induced an approximately $90 \%$ inhibition of mRNA expression, the lack of $\mathrm{Cu}$ effect on gill $\mathrm{Na}^{+} / \mathrm{K}^{+}$-ATPase activity can be explained considering an insertion of pre-existing enzyme units at the basolateral membrane of gill cells. The amount of enzyme units inserted would be enough to maintain the maximum enzyme activity, compensating for the possible inhibitory effect induced by the $\mathrm{Cu}$ exposure. It is important to note that the exposure time used in the present study was $96 \mathrm{~h}$, i.e., a classical condition used in toxicological tests with fish and macroinvertebrates [35]. Perhaps a significant inhibition of the gill $\mathrm{Na}^{+} / \mathrm{K}^{+}$-ATPase activity would be observed with a longer time of exposure to $\mathrm{Cu}$.

As reported for the $\mathrm{Na}^{+} / \mathrm{K}^{+}$-ATPase, an approximately $90 \%$ inhibition of the NaKCC mRNA expression induced by $\mathrm{Cu}$ was also observed in gills of blue crabs acclimated to low salinity ( $2 \%$; Table 2). This gene encodes the $\mathrm{Na}^{+} / \mathrm{K}^{+} / 2 \mathrm{Cl}^{-}$cotransporter, which is a key transporter for $\mathrm{Na}^{+}$and $\mathrm{Cl}^{-}$uptake in weak hyperosmoregulators such as the crabs Carcinus maenas and $C$. sapidus [36-38]. Preliminary evidence suggests that this cotransporter is expressed preferentially in apical membranes of posterior gills of $C$. sapidus, suggesting its involvement in the osmotic control [37]. The significant decrease $(\sim 50 \%)$ in NaKCC gene transcription observed in control blue crabs acclimated to seawater $(30 \%)$ compared with those acclimated to diluted seawater $(2 \%$; Table 2$)$ supports the idea that the $\mathrm{Na}^{+} / \mathrm{K}^{+} / 2 \mathrm{Cl}^{-}$cotransporter is involved in the hemolymph ion regulation in $C$. sapidus.

Considering the important roles of $\mathrm{Na}^{+} / \mathrm{K}^{+}$-ATPase and $\mathrm{Na}^{+} / \mathrm{K}^{+} / 2 \mathrm{Cl}^{-}$cotransporter in the osmoregulatory processes in $C$. sapidus and the marked $\mathrm{Cu}$ effects on the transcription of the genes encoding these proteins in gills of blue crabs acclimated to low salinity ( $2 \%$; Table 2$)$, we suggest that this metal is also a potential osmoregulatory toxicant to $C$. sapidus under this osmotic condition. Unfortunately, it was not possible in the present study to evaluate the influence of the acclimation salinity and the $\mathrm{Cu}$ effect on the activity of the gill $\mathrm{Na}^{+} / \mathrm{K}^{+}$/ $2 \mathrm{Cl}^{-}$cotransporter.

Conversely, no significant effect of $\mathrm{Cu}$ on transcription of the gene encoding the $\mathrm{H}^{+}$-ATPase (Table 2) or the enzyme activity (Fig. 2) was observed in posterior gills of blue crabs acclimated to salinity $2 \%$. Also, no significant difference between control blue crabs acclimated to seawater and diluted seawater was observed (Table 2 and Fig. 2). These results were expected, given that this enzyme is involved mainly in osmoregulatory mechanisms of strong hyperosmoregulators such as freshwater fish and crustaceans such as the rainbow trout and the Chinese crab Eriocheir sinensis, respectively [27,38]. An apical $\mathrm{H}^{+}$-ATPase activity is apparently required to complement the $\mathrm{Na}^{+} / \mathrm{K}^{+}$-ATPase in driving osmoregulatory ion uptake from the dilute medium [39]. It generally occurs together with apical $\mathrm{Na}^{+}$channels (ENaC). This pump is electrically linked to the $\mathrm{ENaC}$, macroscopically affecting the equimolar $\mathrm{Na}^{+} / \mathrm{H}^{+}$ exchange. The cellular substrate for the proton pump is supplied via hydration of $\mathrm{CO}_{2}$ catalyzed by $\mathrm{CA}$ [27].

Data from several molecular and physiological studies have indicated that the $\mathrm{H}^{+}$-ATPase found in gills of weak hyperosmoregulator crabs is not involved in osmoregulatory processes but probably serves in the acidification of intracellular vesicles. This evidence was reported for the shore crab C. maenas, which cannot survive in salinities lower than $8 \%$ [39]. Despite the fact that the blue crab is considered as a moderate osmoregulator, as with the shore crab, it can tolerate salinities as low as $2 \%$ as tested in the present study. Therefore, the $\mathrm{H}^{+}$-ATPase present in gills of the blue crab $C$. sapidus could also be implicated in ion uptake in this crab species as described for the freshwater E. sinensis. However, additional studies should be performed to clarify the possible role of the $\mathrm{H}^{+}$ATPase present in the gill apical membrane in the osmoregulation of the blue crab C. sapidus. Although the $\mathrm{Cu}$ effect on the transcription of the gene encoding the $\mathrm{H}^{+}$-ATPase was not significant in blue crabs acclimated to diluted seawater $(2 \%$ salinity), a noticeable reduction $(\sim 60 \%)$ in mRNA expression was observed (Table 2). This finding reinforces the idea that $\mathrm{Cu}$ is toxic to blue crab $C$. sapidus by disturbing the osmoregulatory processes.

Carbonic anydrase is probably the first nonmetabolic enzyme to be associated with epithelial ion transport. It does not generate transmembrane transport per se but accelerates the $\mathrm{CO}_{2}$ dissociation, providing $\mathrm{H}^{+}$and $\mathrm{HCO}_{3}^{-}$to their respective transporters. An increased branchial $\mathrm{CA}$ activity was observed in blue crabs $C$. sapidus acclimated to low salinity, the magnitude of $\mathrm{CA}$ induction being inversely proportional to the acclimation salinity [40]. In the present study, the CA activity was also higher in posterior gills of control crabs acclimated to diluted seawater than in those acclimated to seawater. However, this increased activity was detected only for total CA (Fig. 3A), not for the cytoplasmic CA (Fig. 3B). Furthermore, no significant change in CA gene transcription as a function of acclimation salinity was observed (Table 2). Physiological studies reveal more than one isoform of CA with different functions. The membrane-associated CA is the isoform related to crab respiration, facilitating $\mathrm{CO}_{2}$ excretion, whereas the cytoplasmic CA isoform would be directly involved in osmotic and ionic regulation [41]. Therefore, the increased total CA activity observed in control blue crabs acclimated to diluted seawater could result from a higher activity and/or expression of the CA membrane-associated isoform.

In summary, data reported here suggest that the mechanism of $\mathrm{Cu}$ toxicity in seawater acclimated crabs (osmoconforming crabs) is clearly not related to metal interaction with the iontransporting proteins analyzed. However, they also indicate that $\mathrm{Cu}$ is a potential osmoregulatory toxicant to $C$. sapidus in diluted seawater, as observed for other osmoregulating crustaceans. Data clearly show that dissolved $\mathrm{Cu}$ at an environmentally relevant concentration $(0.78 \mu \mathrm{M})$ can be toxic to euryhaline crustaceans living in estuaries (diluted seawater). This statement is based on the fact that mRNA expression of some key proteins involved in osmoregulation in these animals was markedly reduced after exposure to an environmentally relevant concentration of $\mathrm{Cu}$. Therefore, it is fundamental to assess the amount of $\mathrm{Cu}$ that is environmentally realistic in order to prevent further damage to those organisms and the whole ecosystem.

Acknowledgement - This study was financially supported by the International Copper Association (New York, NY, USA), the International Development Research Centre (Ottawa, ON, Canada), and the Conselho Nacional de Desenvolvimento Científico e Tecnológico (CNPq, Brasília, Brazil) in the scope of the "Instituto Nacional de Ciência e Tecnologia de Toxicologia Aquática.' A. Bianchini is a research fellow from the Brazilian CNPq (Proc. 304430/2009-9).

\section{REFERENCES}

1. Seeliger U, Knak RB. 1982. Estuarine metal monitoring in Southern Brazil. Mar Pollut Bull 13:197-206. 
2. Baumgarten MGZ, Niencheski LF. 1998. Avaliação da Qualidade Hidroquímica da Área Portuária da Cidade de Rio Grande (RS) Documentos Técnicos Oceanografia-Vol 9. Editora da FURG, Rio Grande, Rio Grande do Sul, Brazil.

3. Engel DW. 1987. Metal regulation and molting in the blue crab, Callinectes sapidus: copper, zinc and metallothionein. Biol Bull 172: 69-82.

4. Engel DW, Brouwer M. 1993. Crustacean as a model for metal metabolism: 1. Effects of the moult cycle on blue crab metal metabolism and metallothioneins. Mar Environ Res 35:1-5.

5. Rainbow PS. 1995. Physiology, physicochemistry and metal uptake-A crustacean perspective. Mar Pollut Bull 31:55-59.

6. Peña MMO, Lee J, Thiele DJ. 1999. A delicate balance: Homeostatic control of copper uptake and distribution. J Nutr 129:1251-1260.

7. Lauren DJ, McDonald DG. 1987. Acclimation to copper by rainbow trout Salmo gairdneri-Physiology. Can J Fish Aquat Sci 44:99-104.

8. Lauren DJ, McDonald DG. 1987. Acclimation to copper by rainbow trout Salmo gairdneri-Biochemistry. Can J Fish Aquat Sci 44:105111.

9. Weeks JM, Jensen FB, Depledge MH. 1993. Acid-base status, haemolymph composition and tissue copper accumulation in the shore crab Carcinus maenas exposed to combined copper and salinity stress. Mar Ecol Prog Ser 97:91-98.

10. Grosell M, Wood CM. 2002. Copper uptake across rainbow trout gills: mechanisms of apical entry. J Exp Biol 205:1179-1188.

11. Grosell M, McDonald MD, Walsh PJ, Wood CM. 2004. Effects of prolonged copper exposure in the marine gulf toadfish (Opsanus beta) II: Copper accumulation, drinking rate and $\mathrm{Na}^{+} / \mathrm{K}^{+}$-ATPase activity in osmoregulatory tissues. Aquat Toxicol 68:263-275.

12. Pinho GLL, Pedroso MS, Rodrigues SC, Souza SS, Bianchini A. 2007. Physiological effects of copper in the euryhaline copepod Acartia tonsa: Waterborne versus waterborne plus dietborne exposure. Aquat Toxicol 84:62-70.

13. Paganini CL, Souza MM, Bianchini A. 2008. Gill ion transport and copper accumulation in the blue crab Callinectes sapidus. Comp Biochem Physiol C 184:461-461.

14. Paquin PR, Santore RC, Wu KB, Kavvadas CD, Di Toro DM. 2000. The biotic ligand model: a model for acute toxicity of metals to aquatic life. Environ Sci Policy 3:S175-S182.

15. Gensemer RW, Naddy RB, Stubblefield WA, Hockett JR, Santore RC, Paquin PR. 2002. Evaluating role of ion composition on the toxicity of copper to Ceriodaphnia dubia in very hard waters. Comp Biochem Physiol C 133:87-92.

16. Handy RD, Baines EH. 2002. Sodium-dependent copper uptake across epithelia: a review of rationale with experimental evidence from gill and intestine. Biochim Biophys Acta 1566:104-115.

17. Vitale AM, Monserrat JM, Castilho P, Rodriguez EM. 1999. Inhibitory effects of cadmium on carbonic anhydrase activity and ionic regulation of the estuarine crab Chasmagnathus granulata (Decapoda Grapsidae). Comp Biochem Physiol C 122:121-129.

18. Mantel LH, Farmer LL. 1983. Osmotic and ionic regulation. In Vernberg EJ, Vernberg WB, eds. The Biology of Crustacea, Vol 5. Academic, New York, NY, USA, pp 53-161.

19. Piller SC, Henry RP, Doeller JE, Kraus D. 1995. A comparison of the gill physiology of two euryhaline species Callinectes sapidus and Callinectes similis: Energy production, transported-related enzymes and osmoregulation as a function of acclimation salinity. J Exp Biol 198:349-358.

20. Drach P, Tchernigovtzeff C. 1967. Sur la method de determination des stades d'intermue et son application génerale aux crustacés. Vie Milieu 18:597-607.

21. Marcuzzo S, Pagel SM, Chaipetti MIS. 1998. A reserva da biosfera da Mata Atlântica no Rio Grande do Sul—Situação atual, ações e perspectivas. In Costa JPO, Lino CF, Albuquerque JL, eds. Série
Cadernos da Biosfera da Mata Atlântica. Conselho Nacional da Reserva da Biosfera da Mata Atlântica, São Paulo City, São Paulo State, Brazil.

22. Martins CMG, Bianchini A. 2009. Metallothionein-like proteins in the blue crab Callinectes sapidus: Effect of water salinity and ions. Comp Biochem Physiol A 152:366-371.

23. Pinho GLL, Bianchini A. 2010. Acute copper toxicity in the euryhaline copepod Acartia tonsa: implications for the development of an estuarine and marine biotic ligand model. Environ Toxicol Chem 29:1834-1840.

24. Bianchini A, Wood CM. 2003. Mechanism of acute silver toxicity in Daphnia magna. Environ Toxicol Chem 22:1361-1367.

25. Tsai JR, Lin HC. 2007. V-type $\mathrm{H}^{+}$-ATPase in the gills of euryhaline crabs during salinity acclimation. $J$ Exp Biol 210:620-327.

26. Péqueux A. 1995. Osmotic regulation in crustacean. J Crustac Biol 15: $1-60$.

27. Kirschner LB. 2004. The mechanism of sodium chloride uptake in hyperregulating aquatic animals. J Exp Biol 207:1439-1452.

28. Bianchini A, Lauer MM, Nery LEM, Colares EP, Monserrat JM, Santos FEA. 2008. Biochemical and physiological adaptations in the estuarine crab Neohelice granulata during salinity acclimation. Comp Biochem Physiol A 151:423-436.

29. Lovett DL, Verzi MP, Burgents JE, Tanner CA, Glomski K, Lee JJ, Towle DW. 2006. Expression profiles of $\mathrm{Na}^{+} / \mathrm{K}^{+}$-ATPase during acute and chronic hypo-osmotic stress in blue crab Callinectes sapidus. Biol Bull 211:58-65.

30. Martins CMG, Barcarolli IF, Menezes EJ, Giacomin MM, Wood CM, Bianchini A. 2010. Acute toxicity, accumulation and tissue distribution of copper in the blue crab Callinectes sapidus acclimated to different salinities: In vivo and in vitro studies. Aquat Toxicol (in press).

31. Wood CM. 2001. Toxic responses of the gill. In Benson WH, Schleuh DW, eds. Target Organ Toxicity in Marine and Freshwater Teleosts. Taylor \& Francis, Washington, DC, pp 1-87.

32. Grosell M, Nielsen C, Bianchini A. 2002. Sodium turnover rate determines sensitivity to acute copper and silver exposure in freshwater animals. Comp Biochem Physiol C 133:287-303.

33. Li J, Lock RAC, Klaren PHM, Swarts HGP, Schuurmans Stekhoven FMAH, Wendelaar Bonga SE, Flik G. 1996. Kinects of $\mathrm{Cu}^{2+}$ inhibition of $\mathrm{Na}^{+} / \mathrm{K}^{+}$-ATPase. Toxicol Lett $87: 1-38$.

34. Li J, Ouabius ES, Wendelaar Bonga SE, Flik G, Lock RAC. 1998. Effects of water-borne copper on branchial chloride cells and $\mathrm{Na}^{+} / \mathrm{K}^{+}$-ATPase activities in Mozambique tilapia (Oreochromis mossambicus). Aquat Toxicol 43:1-11.

35. American Public Health Association. 1999. Standard Methods for the Examination of Water and Wastewaters 20th ed. American Public Health Association, American Water, Works Association, Water Environment Federation, Washington, DC.

36. Riestenpatt S, Onken H, Siebers D. 1996. Active absorption of $\mathrm{Na}^{+}$ and $\mathrm{Cl}^{-}$across the gill epithelium of the shore crab Carcinus maenas: Voltage-clamp and ion-flux studies. J Exp Biol 199:1545-1554.

37. Towle DW, Weihrauch D. 2001. Osmoregulation by gills of euryhaline crabs: molecular analysis of transporters. Am Zool 41:770-780.

38. Freire C, Onken H, McNamara JC. 2008. A structure-function analysis of ion transport and excretory organs in crustaceans. Comp Biochem Physiol A 151:272-304

39. Weihrauch D, Ziegler A, Siebers D, Towle DW. 2001. Molecular characterization of V-type $\mathrm{H}^{+}$-ATPase ( $\beta$-subunit) in gills of euryhaline crabs and its physiological role in osmoregulatory ion uptake. J Exp Mar Biol Ecol 204:25-37.

40. Henry RP, Watts SA. 2001. Early carbonic anhydrase induction in the gills of the blue crab, Callinectes sapidus, during low salinity acclimation is independent of ornithine decarboxylase activity. $J$ Exp Zool 289:350-358.

41. Serrano L, Halanych KM, Henry PR. 2007. Salinity-stimulated changes in expression and activity of two crabonic anhydrase isoforms in the blue crab Callinectes sapidus. J Exp Biol 210:2320-23332. 